\title{
The Development of Building Energy Conservation in China: A Review and Critical Assessment from the Perspective of Policy and Institutional System
}

\author{
Xueliang Yuan ${ }^{1, *,+}$, Xiaoyu Zhang ${ }^{1}$, Jiaxin Liang ${ }^{1,+}$, Qingsong Wang ${ }^{1, \dagger}$ and Jian Zuo ${ }^{2}$ \\ 1 School of Energy and Power Engineering, Shandong University, Jinan 250061, China; \\ 201512894@mail.sdu.edu.cn (X.Z.); jiaxinliang@mail.sdu.edu.cn (J.L.); wqs@sdu.edu.cn (Q.W.) \\ 2 School of Architecture \& Built Environment, The University of Adelaide, Adelaide 5005, Australia; \\ jian.zuo@adelaide.edu.au \\ * Correspondence: yuanxl@sdu.edu.cn; Tel.: +86-531-8839-9372 \\ + These authors contributed equally to this work.
}

Received: 15 August 2017; Accepted: 15 September 2017; Published: 18 September 2017

\begin{abstract}
The rapid development of the building industry has become an important driving force for the fast growing energy use in China. The building industry contributed $26.4 \%$ of China's GDP, and the building energy use accounted for $33 \%$ of the total energy use in China. Building energy conservation plays an important role in reaching the peak of carbon emissions before 2030, which was committed by the Chinese government in the Paris Agreement. Building energy conservation is a complex system. The guidance and support of government policies are one of the important issues. This research analyzed the institutional framework for building energy conservation in China. The roles and functions of each institution were critically reviewed. The policy system for building energy conservation was also analyzed, which included National Laws; Regulations of the State Council; Provisions of Ministries under the State Council; and National Standards, Plans and Programs. The suggestions for further improvements were drawn from the critical analysis such as defining clear and specific responsibility of management institutions, improving regulations and standard system, establishing the market leading mechanism, etc. This research draws an overall picture of the building energy conservation in China from the policy and institutional perspective. Findings provide a useful reference for increasing environmental performance in the building industry.
\end{abstract}

Keywords: building energy conservation; policy; management; sustainability

\section{Introduction}

As the largest developing country in the world, China has achieved a rapid economic growth, with a GDP of 74.41 trillion RMB in 2016 [1]. However, the proportion of the primary industry, the secondary industry and the tertiary industry in China was $8.6 \%, 39.8 \%$, and $51.6 \%$, respectively [1]. Low energy efficiency and the relatively high percentage of the secondary industry have resulted in excessive consumption of fossil energy and massive emission of environmental pollutants. From 2000 to 2015 , the average annual growth rate of GDP is about $8 \%$, which is accompanied by the annual growth of total energy use at $7.7 \%$. China has become the world's largest energy consumer and carbon emitter. As one of the largest contributors to energy use, the building industry has drawn wide attention. Therefore, it is imperative to promote building energy conservation in China. The 13th Five-Year plan specified that the total energy use of China should be controlled within five billion tons of standard coal by 2020 [2]. China also committed at Paris Climate Summit that the carbon emissions would reach the peak by 2030 [3]. The building energy conservation plays a critical role in achieving these targets. 
The building industry is one of the pillar industries in China. In 2015, the total output value of this industry reached 18.08 trillion RMB, which accounted for $26.4 \%$ of GDP in China [4] (Figure 1). The number of enterprises and the number of the employees in the building industry was 80.91 thousand and 50.94 million, respectively. The space area under construction and the completed building area were 12.40 billion $\mathrm{m}^{2}$ and 4.21 billion $\mathrm{m}^{2}$, respectively. The annual completed building area in China was larger than the sum of that in all the developed countries.

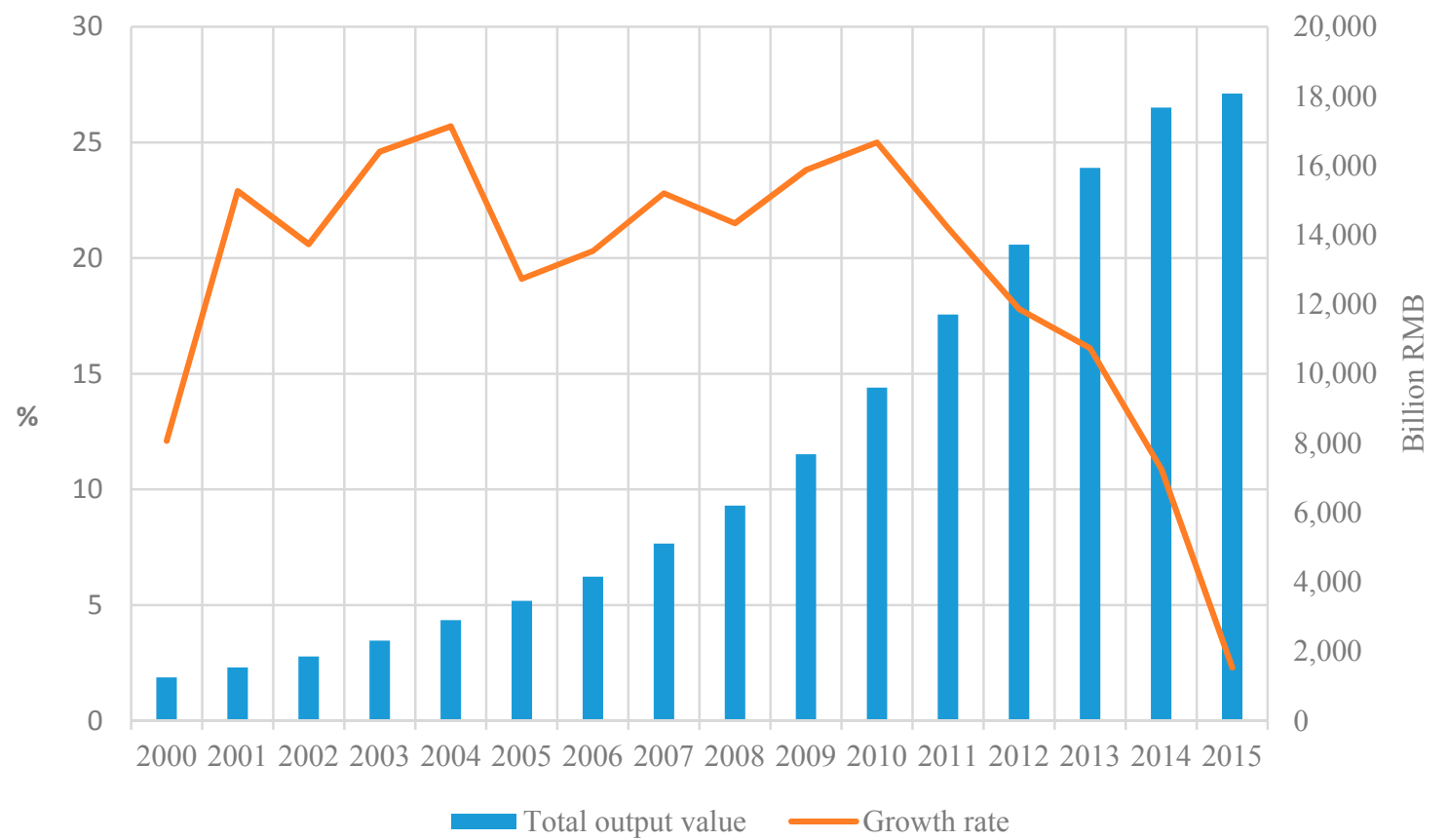

Figure 1. The output value and growth rate of building industry in China from 2000 to 2015 [4].

Building energy use accounts for 40\% of global energy use currently, and the proportion will reach $50 \%$ by 2030 [5]. Total carbon emission in China's building industry has increased from 984.69 million tons of $\mathrm{CO}_{2}$ in 2005 to 3753.98 million tons of $\mathrm{CO}_{2}$ in 2013 [6]. As policies of the building energy conservation are being actively implemented, buildings should improve their energy performance urgently $[7,8]$. Building energy conservation has become one of the major focuses in the energy policy systems of various countries. The policies play a significant role in controlling energy use, such as building energy codes, incentives and energy labels [9]. Similarly, the energy policy can reflect the attitude of the government to energy conservation [10]. The energy tax has become an integral part of the current energy conservation policy in the Netherlands, which provides higher cost effectiveness and more stringent energy efficiency standards for various energy conservation measures [11]. The Chinese government usually adjusts the external problems in building energy market through incentive policies [12]. Guo et al. [13] argued that the government's intervention plays a crucial role in achieving building energy conservation more quickly and efficiently. Their study shows that the operation stage of the building consumes much energy. However, many efforts made by the Chinese government on building energy conservation concentrate on the manufacturers of energy-efficient materials and contractors. As a result, the building users are not enthusiastic on energy conservation due to lack of incentives. Shaikh et al. [14] also points out that maturing the policy plans thus transforming its framework from government regulated to self-regulated industry are important for building energy conservation.

The proportion of building energy use in total energy use is becoming higher globally. This is particularly the case for developing countries. Building energy conservation is a complex system related to different stakeholders and industries. The guidance and support of government policy plays 
an important role. This research analyzed the management mechanism and policy system of building energy use in China. The achievements, experiences and lessons will provide useful references to the development of building energy conservation in other developing countries.

\section{Methodology}

To examine the policy and institutional system of building energy conservation in China, a large number of laws, policies, regulations, standards, plans and programs were reviewed in this paper. These documents were retrieved from the official websites of the government authorities for building energy conservation, as well as the National Bureau of Statistics. Because the first national policy related to building energy conservation was issued in 1986, the time frame of this research is from 1986 to 2017.

The following documents were reviewed:

- National laws

- Regulations of the State Council

- Implementation suggestions and regulations

- Capital subsidies and preferential policies

- National and industrial standards

- Plans and programs

- Statistical Yearbooks and Statistical Bulletins

The role of following government authorities were discussed:

- National Development and Reform Commission (NDRC)

- Ministry of Housing and Urban-Rural Development (MOHURD)

- Ministry of Industry and Information Technology (MIIT)

- General Administration of Quality Supervision, Inspection and Quarantine (AQSIQ)

- National Energy Conservation Center (NECC)

- National Government Offices Administration (NGOA)

- $\quad$ Ministry of Finance (MOF)

- State Administration of Taxation (SAT)

\section{Government Authorities for Building Energy Conservation}

The major government authorities for building energy conservation include: NDRC, MOHURD, MIIT, AQSIQ, NECC, NGOA, MOF, and SAT. These government authorities are responsible for the supervision and management of building energy conservation activities according to their respective responsibilities delegated by the State Council. They complement each other to promote building energy conservation jointly.

NDRC is the macro management institution of building energy conservation. NDRC is responsible for the comprehensive coordination of energy-saving and emission-reduction; organizing and drafting plans and policy measures for energy and resource conservation and comprehensive utilization of the whole society; and coordinating efforts on ecological construction, conservation and comprehensive utilization of energy and resources [15].

MOHURD is responsible for formulating relevant policies and development plans of building energy conservation, and supervising the implementation of these documents. MOHURD is also responsible for organizing the implementation of major building energy conservation projects, guiding the reform of building wall materials, strengthening the management of urban and rural planning. MOHURD is in charge of promoting building energy conservation and urban emission reduction [16].

MIIT is responsible for the management of building materials industry, which includes: (1) structural materials such as cement, brick, and glass; (2) decoration materials such as coating, paint, and ceramics; and (3) special material for thermal insulation and sound insulation [17]. 
AQSIQ is in charge of the formulation, revision and approval of national standards related to building energy conservation. The national standards for building energy conservation are jointly released by AQSIQ and MOHURD [16,18].

NECC is a sub-institution of NDRC. It is responsible for energy auditing, energy efficiency benchmarking, energy performance contracting, demand side management, new mechanism of building energy conservation, etc. NECC provides guidance and service for the industries, local energy conservation center, supervision institution of energy conservation and technical service institutions. The supervision of building energy conservation is an important duty of NECC.

NGOA is responsible for the management and supervision of energy conservation of the central government's public institutions. It provides guidance to the governmental departments of education, science and technology, culture, and health to carry out building energy conservation activities in public institutions. NGOA is also responsible for the formulation and implementation of plans for energy conservation projects, energy conservation of existing buildings and reform of heating metering system [19].

MOF formulates financial subsidy policies for building energy conservation and green building. It is responsible for regulating and strengthening the management of the subsidy funds of energy conservation and emission reduction, as well as improving the benefits of the financial subsidy [20].

SAT formulates policies of tax reimbursement and tax preferences for the building energy conservation industry. It is responsible for developing the preferential policy of value added tax for energy-saving materials [21].

The management institutions of government departments and the corresponding responsibilities are shown in Figure 2.

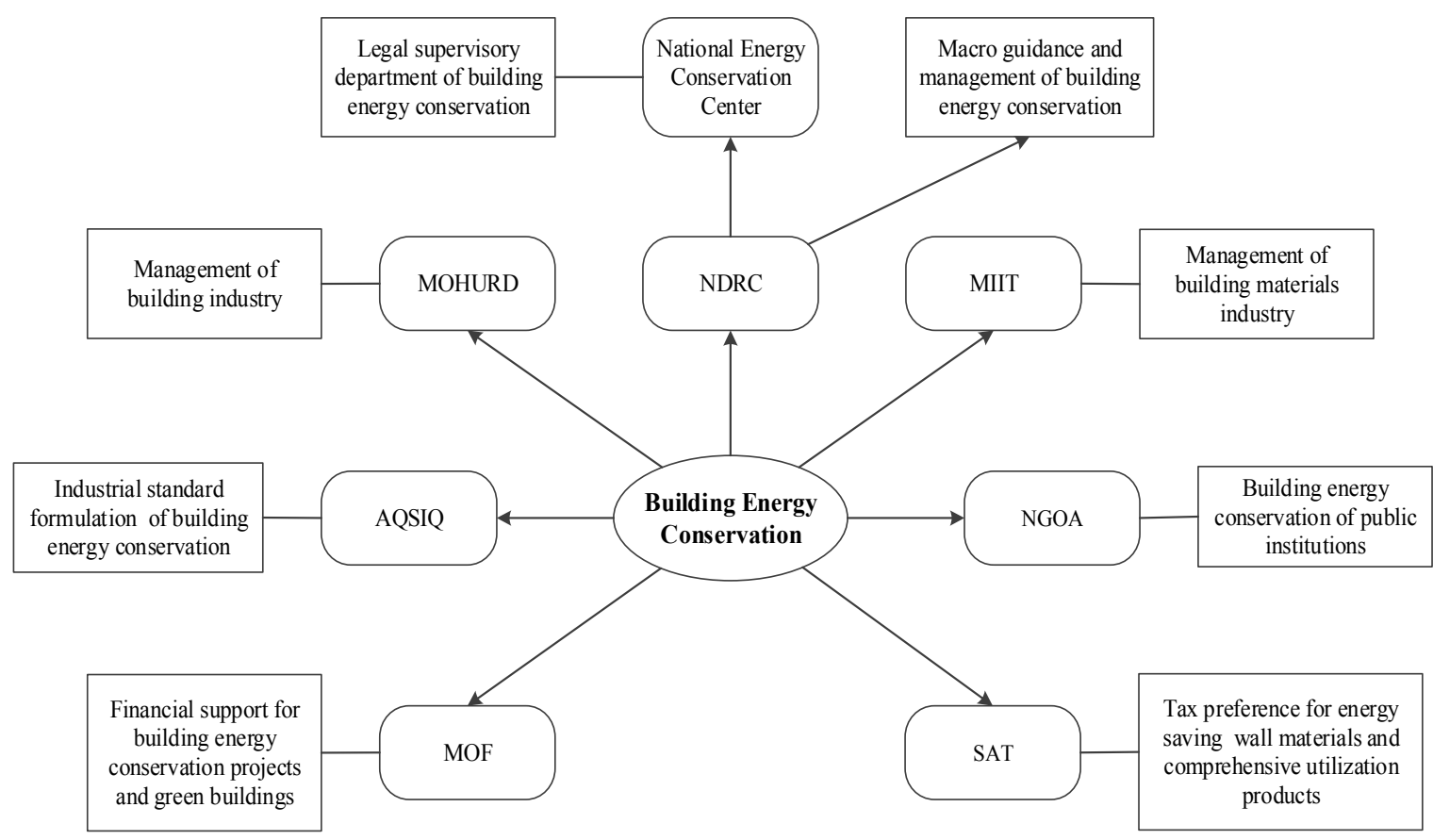

Figure 2. The government authorities for building energy conservation in China.

\section{Policy System of Building Energy Conservation}

China's policies related to building energy conservation can be classified into three levels. The first level is national laws approved by the Standing Committee of the National People's Congress (SCNPC) in the form of the presidential order. The second level is regulations of the State Council approved by the State Council in the form of the State Council's order. The third level is department rules, standards and plans approved by ministries and departments under the State Council (Figure 3). 


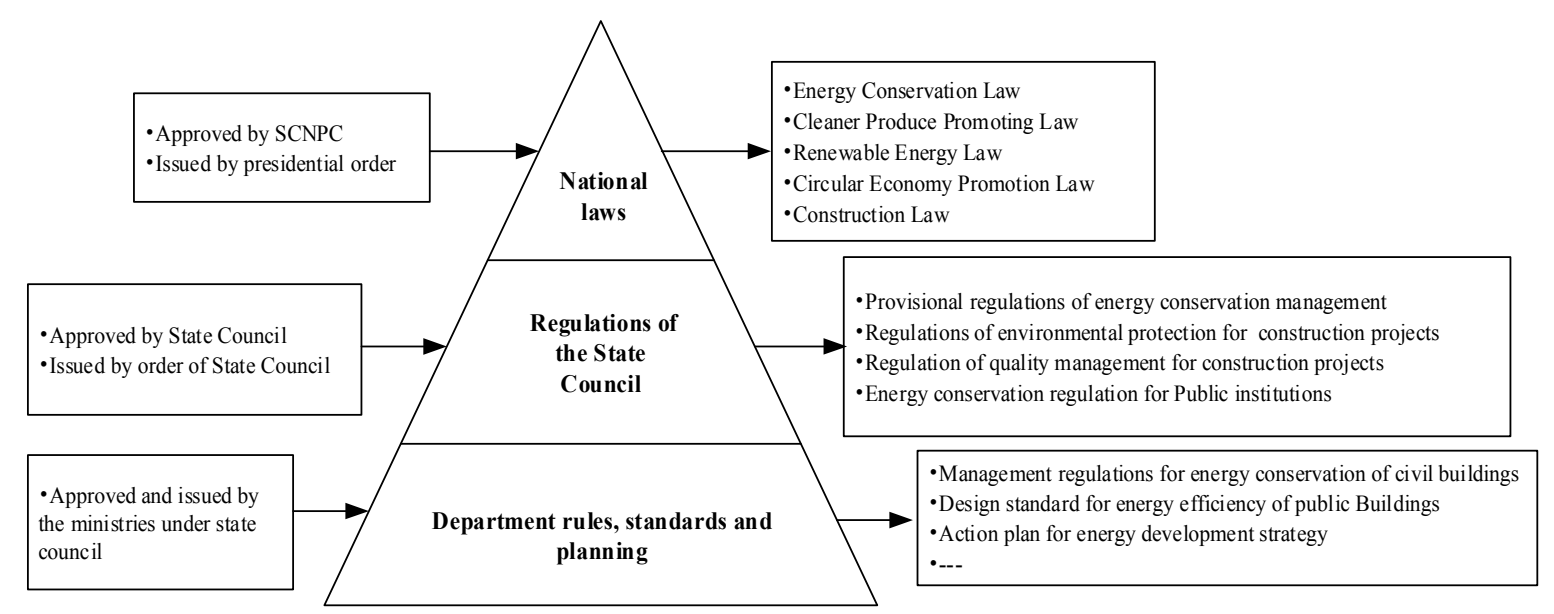

Figure 3. The policy system of building energy conservation in China.

\subsection{National Laws}

As the legal basis at the national level, there are five national laws for the building energy conservation: Energy Conservation Law, Cleaner Production Promotion Law, Renewable Energy Law, Circular Economy Promotion Law, and Construction Law (Table 1). These laws form the legal status of building energy conservation, which also make clear that MOHURD is the government authority for the building industry. These laws have established the evaluation and examination system for energy conservation projects; and specify requirements of building energy conservation from aspects of building design, construction, use, as well as the selection of building materials and the implementation of renewable energy. However, the institutions of law enforcement and the corresponding rights and obligations need to be specified. In the promotion laws, it contains many recommended terms, which are not beneficial for energy conservation.

\subsection{Regulations of the State Council}

The regulations of the State Council belong to administrative regulations, which have the nature of legal documents and are consistent with the effect of laws in the process of implementation. At present, there are five relevant regulations of the State Council on building energy conservation: Provisional Regulations of Management for Energy Conservation, Regulations on the Administration for Environmental Protection of Construction Projects, Regulations on the Quality Management of Construction Projects, Regulations on Energy Conservation of State-funded Institutions and Regulation on Energy Conservation of Civil Buildings (Table 2).

The regulations of the State Council have more specific contents than the national laws. More attention is paid to the details of building energy conservation. They are important supplement to the national laws. Provisional Regulation of Management for Energy Conservation focuses on the design of building energy efficiency and central heating system. From the perspective of reducing environmental pollution, Regulation on the Administration for Environmental Protection of Construction Projects requires industry practitioners to use building materials and processes with low energy use. Regulation on the Quality Management of Construction Projects stipulates that building quality is the fundamental premise of building energy conservation. Regulation on Energy Conservation of State-funded Institutions and Regulation on Energy Conservation of Civil Buildings sets the specific requirements of building energy conservation for public and civil buildings. However, energy conservation is not the core in some documents such as Regulation on the Administration for Environmental Protection of Construction Projects. The focus in different time frames should also be specified due to the large amount of buildings. 
Table 1. National laws related to building energy conservation.

\begin{tabular}{|c|c|c|c|c|}
\hline Title & Date of Issue & Date of Implementation & Related Contents & Comments \\
\hline Energy Conservation Law [22] & $\begin{array}{l}1 \text { November } 1997 \\
28 \text { October } 2007 \\
\text { (Revision) } \\
2 \text { July 2016 } \\
\text { (Revision) }\end{array}$ & 1 January 1998 & $\begin{array}{l}\text { The Construction Department in the State Council is } \\
\text { responsible for the supervision and management of building } \\
\text { energy conservation. The State shall implement the energy } \\
\text { conservation evaluation and examination system for } \\
\text { investment projects of fixed asset. The construction, design } \\
\text { and supervision units of construction projects shall comply } \\
\text { with the standards for building energy efficiency. } \\
\text { It encourages the use of new wall materials and other energy } \\
\text { conservation building materials and energy conservation } \\
\text { equipment in the transformation of new buildings and } \\
\text { existing buildings. It encourages the installation and use of } \\
\text { solar energy and other renewable energy utilization systems. }\end{array}$ & $\begin{array}{l}\text { The first national law about energy } \\
\text { conservation. It confirms the strategic } \\
\text { position of energy conservation in the } \\
\text { development of national economic and } \\
\text { society. However, the institutions of law } \\
\text { enforcement are not clear. } \\
\text { The corresponding rights and obligations } \\
\text { need to be specified. }\end{array}$ \\
\hline $\begin{array}{l}\text { Cleaner Production Promotion } \\
\text { Law [23] }\end{array}$ & $\begin{array}{l}29 \text { June } 2002 \\
29 \text { June } 2012 \\
\text { (Revision) }\end{array}$ & 1 January 2003 & $\begin{array}{l}\text { This law requires that the construction project should adopt } \\
\text { architectural design schemes and building decoration } \\
\text { materials and construction fittings and equipment which in } \\
\text { accordance with energy conservation, water conservation and } \\
\text { resource protection. }\end{array}$ & $\begin{array}{l}\text { It has some requirements from the } \\
\text { whole-life-cycle perspective. As a } \\
\text { promotion law, it contains many } \\
\text { recommended terms. }\end{array}$ \\
\hline Renewable Energy Law [24] & 28 February 2005 & 1 January 2006 & $\begin{array}{l}\text { Units and individuals are encouraged to install and use solar } \\
\text { water heating systems, solar heating and cooling systems, } \\
\text { solar photovoltaic power systems. The technical and } \\
\text { economic policies and technical specifications of combining } \\
\text { solar energy utilization system with building shall be } \\
\text { formulated by the construction administrative departments } \\
\text { and the relevant departments under the State Council. }\end{array}$ & $\begin{array}{l}\text { Renewable Energy Law is beneficial to } \\
\text { achieve energy conservation from the input } \\
\text { side. However, the social acceptance, } \\
\text { especially solar PV should be strengthened. }\end{array}$ \\
\hline $\begin{array}{l}\text { Circular Economy Promotion } \\
\text { Law [25] }\end{array}$ & 29 August 2008 & 1 January 2009 & $\begin{array}{l}\text { The units of building design and construction shall use } \\
\text { energy conservation technologies for the design and } \\
\text { construction of buildings and structures according to relevant } \\
\text { state regulations and standards. Renewable energy, such as } \\
\text { solar energy, geothermal energy, wind energy, etc., should be } \\
\text { fully utilized in the areas with conditions. }\end{array}$ & $\begin{array}{l}\text { It has some requirements from the } \\
\text { whole-life-cycle perspective. As a } \\
\text { promotion law, it contains } 1 \text { many } \\
\text { recommended terms. }\end{array}$ \\
\hline Construction Law [26] & 22 April 2011 & 1 July 2011 & $\begin{array}{l}\text { The State supports the research of building science and } \\
\text { technology to improve the level of housing design, encourage } \\
\text { energy conservation and environmental protection. The State } \\
\text { encourages the use of advanced technology and equipment, } \\
\text { new building materials, and modern management. }\end{array}$ & $\begin{array}{l}\text { The first specific law about buildings. } \\
\text { However, contents related to building } \\
\text { energy conservation are not the major role. }\end{array}$ \\
\hline
\end{tabular}


Table 2. Regulations of the State Council related to building energy conservation.

\begin{tabular}{|c|c|c|c|c|}
\hline Title & Date of Issue & Date of Implementation & Related Contents & Comments \\
\hline $\begin{array}{l}\text { Provisional Regulation of } \\
\text { Management for Energy } \\
\text { Conservation [27] }\end{array}$ & 12 January 1986 & 1 April 1986 & $\begin{array}{l}\text { In building design stage, the shape and orientation of the } \\
\text { building shall be properly determined, improve the envelope, } \\
\text { choose low energy facilities, reduce energy use for lighting, } \\
\text { heating and cooling. The central heating system should be } \\
\text { used in all newly built heating residential buildings and } \\
\text { public buildings. }\end{array}$ & $\begin{array}{l}\text { The first regulation of the State } \\
\text { Council related to building } \\
\text { energy conservation. Energy } \\
\text { saving measures are stipulated } \\
\text { in various aspects. }\end{array}$ \\
\hline $\begin{array}{l}\text { Regulation on the } \\
\text { Administration for } \\
\text { Environmental Protection of } \\
\text { Construction Projects [28] }\end{array}$ & $\begin{array}{l}18 \text { November } 1998 \\
17 \text { April } 2016 \\
\text { (Revision) }\end{array}$ & 29 November 1998 & $\begin{array}{l}\text { The clean production process, which has low energy and } \\
\text { material consumption and less generation of pollutants, } \\
\text { should be used in industrial construction projects. Natural } \\
\text { resources should be utilized reasonably, environmental } \\
\text { pollution and ecological damage should be prevented. }\end{array}$ & $\begin{array}{l}\text { It was formulated to prevent } \\
\text { pollution from the construction } \\
\text { projects, as well as resource } \\
\text { conservation. However, energy } \\
\text { conservation is not the core. }\end{array}$ \\
\hline $\begin{array}{l}\text { Regulation on Quality } \\
\text { Management of Construction } \\
\text { Projects [29] }\end{array}$ & 30 January 2000 & 30 January 2000 & $\begin{array}{l}\text { It specifies the responsibilities and obligations of the } \\
\text { construction units, survey units, design units, construction } \\
\text { units, engineering supervision units in the aspect of } \\
\text { construction quality. }\end{array}$ & $\begin{array}{l}\text { It was formulated to ensure the } \\
\text { quality of construction projects. }\end{array}$ \\
\hline $\begin{array}{l}\text { Regulation on Energy } \\
\text { Conservation of State-funded } \\
\text { Institutions [30] }\end{array}$ & 23 July 2008 & 1 October 2008 & $\begin{array}{l}\text { NGOA is responsible for promoting, guiding, coordinating } \\
\text { and supervising of energy conservation for public institutions. } \\
\text { Public institutions should strengthen the management of } \\
\text { energy use, reduce energy use, eliminate energy waste, and } \\
\text { make effective and rational use of energy. }\end{array}$ & $\begin{array}{l}\text { The regulation related to energy } \\
\text { conservation of public } \\
\text { institutions, which has obvious } \\
\text { effect due to the attribute of the } \\
\text { building. }\end{array}$ \\
\hline $\begin{array}{l}\text { Regulation on Energy } \\
\text { Conservation of Civil } \\
\text { Buildings [31] }\end{array}$ & 1 August 2008 & 1 October 2008 & $\begin{array}{l}\text { The construction department MHURD is responsible for the } \\
\text { supervision and administration of civil building energy } \\
\text { conservation. Civil building energy conservation includes } \\
\text { energy conservation of new buildings, energy conservation of } \\
\text { existing buildings, and energy conservation of operation for } \\
\text { building energy systems. }\end{array}$ & $\begin{array}{l}\text { The regulation related to energy } \\
\text { conservation of civic buildings. } \\
\text { The major field needs to be } \\
\text { specified since there are many } \\
\text { civil buildings. }\end{array}$ \\
\hline
\end{tabular}




\subsection{Department Rules, Standards and Plans}

\subsubsection{Department Rules}

A. Implementation Suggestions and Regulations

MOHURD, NDRC, MOF and other authorities have issued 13 implementation suggestions and regulations (see Table 3). These implementation suggestions and regulations specify the overarching goals and requirements of building energy conservation. By 2020, the level of energy and resource consumption of residential and public buildings will be improved to the level of the moderately developed countries. The renewable energy will contribute $15 \%$ of total building energy use. These documents specify that energy conservation supervision system should be established for government office buildings and large-scale public buildings so that the mandatory standards for building energy conservation of new buildings can be implemented. Innovative energy conservation mechanisms such as energy efficiency trading and energy performance contracting shall be promoted. The development of green building and sustainable materials shall be encouraged. It is also clearly specified in these documents that the following areas will be strengthened and promoted: renewable energy applications in buildings, energy audit for public institutions, and energy use monitoring platform for public buildings.

\section{B. Capital Subsidies and Preferential Policies}

To promote the building energy conservation, financial subsidies or credit support are provided to initiatives such as the regulation of building energy use, building energy-saving renovation, production of energy conservation building materials and renewable energy applications. The specific policies and measures are shown in Table 4.

MOF arranges special funds to support the building energy conservation of government office buildings and large-scale public buildings, and provides one-off quota subsidies for setting up the energy use monitoring platform. For energy-saving retrofitting of heating system in buildings, the capital subsidy is granted according to climate zones: $55 \mathrm{RMB} / \mathrm{m}^{2}$ for very cold regions and $45 \mathrm{RMB} / \mathrm{m}^{2}$ for cold regions. Solar photovoltaic, ground source heat pump and integrated solar thermal technology receives the financial support of $13-17 \mathrm{RMB} / \mathrm{W}, 60 \mathrm{RMB} / \mathrm{m}^{2}$ and $15 \mathrm{RMB} / \mathrm{m}^{2}$, respectively. Each demonstration city of integrated renewable energy utilization in buildings is granted a subsidy of 50 million RMB. While in the course of policy implementation, the financial subsidies may not in place sometimes, and the renewable energy sources cannot be widely used.

\subsubsection{National Standards and Industrial Standards}

Building energy conservation standards include two national standards and seven industrial standards (see Table 5). Design Standard for Energy Conservation of Civil Buildings (Heating Residential Buildings) (JGJ26-86) is the first standard for energy conservation, which is a symbolic document to promote the development of this sector. Other standards provide specific standards and requirements from the aspects of building energy conservation design and inspection, green building evaluation, green transformation of existing buildings, etc. Most of the 13 standards related to building energy conservation are recommended standards. The national mandatory standards only include Design Standard for Energy Efficiency of Public Buildings (GB 50189-2005, GB 50189-2015), Technical Standard for Solar Water Heating System of Civil Building (GB 50364-2005), and Standard for Acceptance of Energy Efficient Building Construction (GB 50411-2007). Therefore, efforts are required to strengthen and improve the effects of the mandatory standards to promote the building energy conservation. 


\subsubsection{Plans and Programs}

The plans and programs related to building energy conservation reflect the current focus and future directions. Compared with laws, regulations and standards, plans and programs have more specific contents with time effectiveness (see Table 6). These documents have focused on: implementing building energy efficiency projects; promoting residential building design standard for energy conservation; developing passive ultra-low energy use green buildings; implementing renovation and transformation of aged residential buildings; improving the building energy conservation standards; developing the energy and resource conservation management system; developing green building materials; constructing green buildings; and comprehensively promoting energy conservation in buildings and public institutions. By 2020, the total energy use of public institutions will be controlled to less than 225 million tce. The energy use per capita and per unit building area will decrease by $11 \%$ and $10 \%$, respectively. Urban green building will account for $50 \%$ of new building. The energy-saving retrofitting area of existing residential buildings and public buildings will exceed 500 million $\mathrm{m}^{2}$ and 100 million $\mathrm{m}^{2}$, respectively. The accumulated installation area of solar water heater system and heat collection area of solar thermal utilization will reach 450 million $\mathrm{m}^{2}$ and 800 million $\mathrm{m}^{2}$, respectively.

In summary, the building energy conservation policies are a complex system which includes national laws, regulations of the State Council, standards and planning. From 1986 to 2017, more than 50 documents were issued. Figure 4 shows these documents in line of time axis.

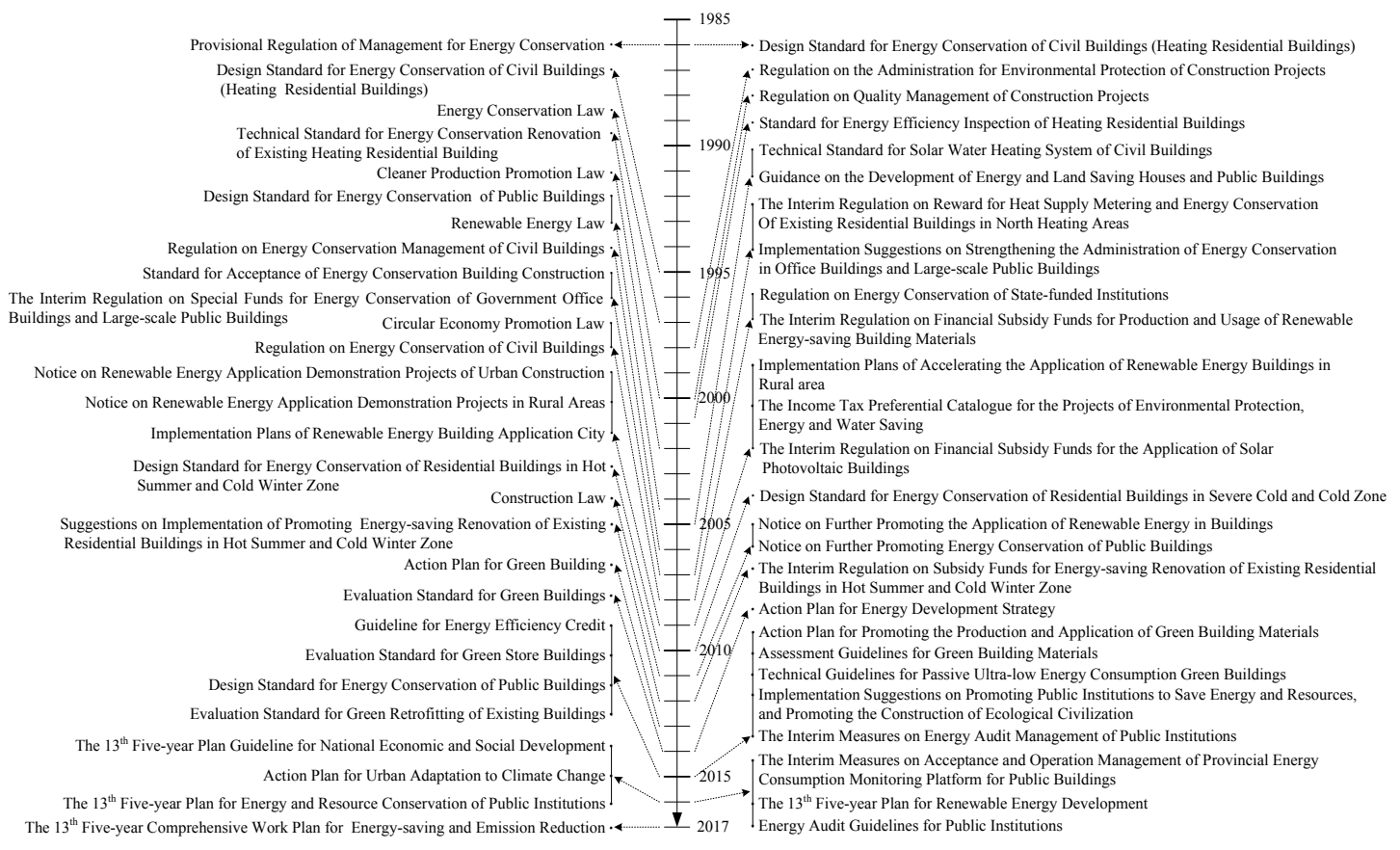

Figure 4. Documents related to building energy conservation in China. 
Table 3. Implementation suggestions and regulations related to building energy conservation.

\begin{tabular}{|c|c|c|c|}
\hline Title & Department of Issue & Date of Issue & Related Contents \\
\hline $\begin{array}{l}\text { Guidance on the Development of Energy } \\
\text { and Land Saving Houses and Public } \\
\text { Buildings [32] }\end{array}$ & MHURD & 31 May 2005 & $\begin{array}{l}\text { By 2020, the new buildings should achieve } 65 \% \text { of energy-saving and existing } \\
\text { buildings should complete energy-saving reconstruction in North China and the } \\
\text { economically developed coastal areas and large cities. The total consumption of } \\
\text { non-renewable resources in new buildings will decrease } 20 \% \text { at the level of } 2010\end{array}$ \\
\hline $\begin{array}{l}\text { Regulation on Energy Conservation } \\
\text { Management of Civil Buildings [33] }\end{array}$ & MHURD & 1 January 2006 & $\begin{array}{l}\text { Construction department is responsible for the formulation of national and local } \\
\text { building energy conservation plans and standards. The development of new } \\
\text { technologies and products for building energy conservation is encouraged. } \\
\text { The violations of the mandatory standards for building energy efficiency design } \\
\text { will be punished. }\end{array}$ \\
\hline $\begin{array}{l}\text { Implementation Suggestions on } \\
\text { Strengthening the Administration of } \\
\text { Energy Conservation in Office Buildings } \\
\text { and Large-scale Public Buildings [34] }\end{array}$ & $\begin{array}{l}\text { MHURD } \\
\text { MOF }\end{array}$ & 23 October 2007 & $\begin{array}{l}\text { Establish and improve the energy conservation supervision system of governmen } \\
\text { office buildings and large-scale public buildings. Ensure the full implementation } \\
\text { energy conservation mandatory standards of newly built buildings. Promote } \\
\text { energy conservation operation and renovation of existing government office } \\
\text { buildings and large-scale public buildings with high energy use. }\end{array}$ \\
\hline $\begin{array}{l}\text { Notice on Renewable Energy } \\
\text { Application Demonstration Projects of } \\
\text { Urban Construction [35] }\end{array}$ & $\begin{array}{l}\text { MOF } \\
\text { MHURD }\end{array}$ & 6 July 2009 & $\begin{array}{l}\text { The state organize renewable energy application demonstration projects of urbar } \\
\text { construction to promote the large-scale application of renewable energy in the } \\
\text { building industry; Strengthen the supporting capacity such as technical standard } \\
\text { to form an effective model of promoting renewable energy applications. }\end{array}$ \\
\hline $\begin{array}{l}\text { Notice on Renewable Energy } \\
\text { Application Demonstration Projects in } \\
\text { Rural Areas [36] }\end{array}$ & $\begin{array}{c}\text { MOF } \\
\text { MOHURD }\end{array}$ & 6 July 2009 & $\begin{array}{l}\text { The state support renewable energy construction applications in rural primary } \\
\text { and secondary schools, the integrated application of renewable energy and } \\
\text { building in counties (towns), rural residential buildings and health centers, et al } \\
\text { the State }\end{array}$ \\
\hline $\begin{array}{l}\text { Notice on Further Promoting the } \\
\text { Application of Renewable Energy in } \\
\text { Buildings [37] }\end{array}$ & $\begin{array}{c}\text { MOF } \\
\text { MOHURD }\end{array}$ & 8 March 2011 & $\begin{array}{l}\text { Raise the proportion of solar energy, geothermal energy, biomass energy and } \\
\text { other renewable energy in building energy use. Renewable energy will account } \\
\text { for more than } 15 \% \text { of building energy use by } 2020 \text {. }\end{array}$ \\
\hline $\begin{array}{l}\text { Notice on Further Promoting Energy } \\
\text { Conservation of Public Buildings [38] }\end{array}$ & $\begin{array}{c}\text { MOF } \\
\text { MOHURD }\end{array}$ & 4 May 2011 & $\begin{array}{l}\text { Strengthen energy conservation management of new public buildings. Develop } \\
\text { the energy conservation supervision system of public buildings. Promote energy } \\
\text { efficiency trading and energy performance contracting and other new energy } \\
\text { conservation mechanism actively. }\end{array}$ \\
\hline $\begin{array}{l}\text { Assessment Guidelines for Green } \\
\text { Building Materials [39] }\end{array}$ & $\begin{array}{l}\text { MOHURD } \\
\text { MIIT }\end{array}$ & 14 October 2015 & $\begin{array}{l}\text { Formulate seven evaluation technological requirements of green building } \\
\text { materials, i.e., masonry materials, insulation materials, ready-mixed concrete, } \\
\text { building energy-saving glass, ceramic brick, sanitary pottery, and } \\
\text { ready-mixed mortar. }\end{array}$ \\
\hline $\begin{array}{l}\text { Technical Guidelines for Passive } \\
\text { Ultra-low Energy use Green Buildings } \\
\text { (Trial Implementation in Residential } \\
\text { Buildings) [40] }\end{array}$ & MOHURD & 10 November 2015 & $\begin{array}{l}\text { Make clear the definition of the passive ultra-low energy use green building, the } \\
\text { technical indexes of different climate regions and the technical emphasis of } \\
\text { design, construction, operation and evaluation. This provides guidance for the } \\
\text { construction of the national passive ultra-low energy use green buildings. }\end{array}$ \\
\hline
\end{tabular}


Table 3. Cont

\begin{tabular}{|c|c|c|c|}
\hline Title & Department of Issue & Date of Issue & Related Contents \\
\hline $\begin{array}{l}\text { Implementation Suggestions on } \\
\text { Promoting Public Institutions to Save } \\
\text { Energy and Resources, and Promoting } \\
\text { the Construction of Ecological } \\
\text { Civilization [41] }\end{array}$ & $\begin{array}{c}\text { NGOA } \\
\text { NDRC } \\
\text { MOF }\end{array}$ & 30 December 2015 & $\begin{array}{l}\text { The building energy conservation standards and the energy conservation } \\
\text { evaluation assessment system of construction projects should be enforced strictly. } \\
\text { Public buildings should take the lead in implementing green building standards. } \\
\text { Promote the energy-saving renovation of existing buildings, facilities and } \\
\text { equipment. Promote the application of new technology, new materials, new } \\
\text { products, solar energy and other renewable energies for energy conversation and } \\
\text { environment protection. }\end{array}$ \\
\hline $\begin{array}{l}\text { The Interim Measures on Energy Audit } \\
\text { Management of Public Institutions [42] }\end{array}$ & $\begin{array}{l}\text { NDRC } \\
\text { NGOA }\end{array}$ & 31 December 2015 & $\begin{array}{l}\text { Public institutions and centralized offices with annual energy use more than } \\
500 \text { tce or annual power consumption more than } 2 \text { million } \mathrm{kWh} \text { or construction } \\
\text { area larger than } 10 \text { thousand } \mathrm{m}^{3} \text { should carry out energy audits every } 5 \text { years and } \\
\text { be subsumed into the scope of government procurement services. }\end{array}$ \\
\hline $\begin{array}{l}\text { The Interim Measures on Acceptance } \\
\text { and Operation Management of } \\
\text { Provincial Energy use Monitoring } \\
\text { Platform for Public Buildings [43] }\end{array}$ & MOHURD & 11 April 2016 & $\begin{array}{l}\text { The acceptance evaluation of provincial energy use monitoring platform for } \\
\text { public building is standardized. The conditions and procedures of acceptance is } \\
\text { made clear to ensure the construction quality and operation efficiency of the } \\
\text { provincial public building energy use monitoring platform. }\end{array}$ \\
\hline $\begin{array}{l}\text { Energy Audit Guidelines for Public } \\
\text { Institutions [44] }\end{array}$ & MOHURD & 2 December 2016 & $\begin{array}{l}\text { Building energy audit mainly aim at monitor, diagnose and evaluate of building } \\
\text { envelope, power systems, heating, ventilation and air conditioning (HVAC) } \\
\text { systems and renewable energy systems. It applies to all types of single public } \\
\text { buildings. }\end{array}$ \\
\hline
\end{tabular}

Table 4. Capital subsidy and preferential policies related to building energy conservation.

\begin{tabular}{|c|c|c|c|}
\hline Title & Department of Issue & Date of Issue & Related Contents \\
\hline $\begin{array}{l}\text { The Interim Regulation on Special Funds } \\
\text { for Energy Conservation of Government } \\
\text { Office Buildings and Large-scale Public } \\
\text { Buildings [45] }\end{array}$ & MOF & 24 October 2007 & $\begin{array}{l}\text { The central finance supports the construction of energy use supervision system for } \\
\text { government office buildings and large-scale public buildings with one-time quota } \\
\text { subsidies. Special funds will be arranged to support the building energy conservation } \\
\text { of government office buildings and large-scale public buildings. }\end{array}$ \\
\hline $\begin{array}{l}\text { The Interim Regulation on Reward for } \\
\text { Heat Supply Metering and Energy } \\
\text { Conservation of Existing Residential } \\
\text { Buildings in North Heating Areas [46] }\end{array}$ & MOF & 20 December 2007 & $\begin{array}{l}\text { Implement the renovation of heat supply metering and energy conservation in } \\
\text { existing residential buildings in north heating areas. The reward basis of different } \\
\text { climatic regions is } 55 \mathrm{RMB} / \mathrm{m}^{2} \text { and } 45 \mathrm{RMB} / \mathrm{m}^{2} \text { for severe cold area and cold } \\
\text { area, respectively. }\end{array}$ \\
\hline $\begin{array}{l}\text { The Interim Regulation on Financial } \\
\text { Subsidy Funds for Production and Usage } \\
\text { of Renewable Energy-saving Building } \\
\text { Materials [47] }\end{array}$ & MOF & 14 October 2008 & $\begin{array}{l}\text { The central finance arranges special funds to support the production and application } \\
\text { of renewable energy conservation building materials, which includes the subsidized } \\
\text { interest for expanding business of renewable energy conservation building materials, } \\
\text { reward for promotion and application of renewable energy conservation building } \\
\text { materials, research and development of relevant technical standards and } \\
\text { specifications. }\end{array}$ \\
\hline
\end{tabular}


Table 4. Cont.

\begin{tabular}{|c|c|c|c|}
\hline Title & Department of Issue & Date of Issue & Related Contents \\
\hline $\begin{array}{l}\text { The Interim Regulation on Financial } \\
\text { Subsidy Funds for the Application of } \\
\text { Solar Photovoltaic Buildings [48] }\end{array}$ & MOF & 23 March 2009 & $\begin{array}{l}\text { Single project with the installed capacity of solar photovoltaic products larger than } \\
50 \mathrm{kWp} \text { can get financial subsidies. Priority support of } 13-17 \mathrm{RMB} / \mathrm{W} \text { will be } \\
\text { arranged for the integration project of solar photovoltaic application and building, } \\
\text { grid-connected solar photovoltaic building application projects. }\end{array}$ \\
\hline $\begin{array}{l}\text { Implementation Plans of Renewable } \\
\text { Energy Building Application City [49] }\end{array}$ & $\begin{array}{c}\text { MOF } \\
\text { MOHURD }\end{array}$ & 6 July 2009 & $\begin{array}{l}\text { Each demonstration city of renewable energy building application can get subsidy } \\
\text { funds for } 50 \text { million RMB. The city has large area of promotion and application, } \\
\text { advanced and applicable technology type, and good energy substitution effect can get } \\
\text { maximum subsidy funds for no more than } 80 \text { million RMB. }\end{array}$ \\
\hline $\begin{array}{l}\text { Implementation Plans of Accelerating } \\
\text { the Application of Renewable Energy } \\
\text { Buildings in Rural area [50] }\end{array}$ & $\begin{array}{c}\text { MOF } \\
\text { MOHURD }\end{array}$ & 6 July 2009 & $\begin{array}{l}\text { Subsidy standard for ground source heat pump technology application and } \\
\text { integrated solar thermal utilization is } 60 \mathrm{RMB} / \mathrm{m}^{2} \text { and } 15 \mathrm{RMB} / \mathrm{m}^{2} \text {. Solar energy } \\
\text { bathroom and solar house can get subsidies for } 60 \% \text { of investment. }\end{array}$ \\
\hline $\begin{array}{l}\text { The Income Tax Preferential Catalogue } \\
\text { for the Projects of Environmental } \\
\text { Protection, Energy and Water Saving [ } 51]\end{array}$ & $\begin{array}{l}\text { MOF } \\
\text { SAT } \\
\text { NDRC }\end{array}$ & 31 December 2009 & $\begin{array}{l}\text { Income tax preferential projects include: energy-saving renovation projects of existing } \\
\text { high energy use buildings, integrated technology of solar thermal and solar } \\
\text { photovoltaic existing buildings, shallow geothermal energy heat pump technological } \\
\text { transformation, heat supply metering and energy-saving renovation of existing } \\
\text { residential buildings. }\end{array}$ \\
\hline $\begin{array}{l}\text { Suggestions on Implementation of } \\
\text { Promoting Energy-saving Renovation of } \\
\text { Existing Residential Buildings in Hot } \\
\text { Summer and Cold Winter Zone [52] }\end{array}$ & $\begin{array}{c}\text { MOF } \\
\text { MOHURD }\end{array}$ & 1 April 2012 & $\begin{array}{l}\text { The central finance allocates special funds to support the energy-saving renovation of } \\
\text { existing residential buildings in hot summer and cold winter zone. Local finance } \\
\text { should take energy-saving renovation as the key point of the energy-saving and } \\
\text { emission-reduction financial arrangement. }\end{array}$ \\
\hline $\begin{array}{l}\text { The Interim Regulation on Subsidy } \\
\text { Funds for Energy-saving Renovation of } \\
\text { Existing Residential Buildings in Hot } \\
\text { Summer and Cold Winter Zone [53] }\end{array}$ & MOF & 9 April 2012 & $\begin{array}{l}\text { Energy-saving renovation projects of existing high energy use buildings in hot } \\
\text { summer and cold winter areas since } 2012 \text { can get subsidies from the central finance. }\end{array}$ \\
\hline $\begin{array}{l}\text { Guideline for Energy Efficiency } \\
\text { Credit [54] }\end{array}$ & $\begin{array}{l}\text { CBRC } \\
\text { NDRC }\end{array}$ & 13 January 2015 & $\begin{array}{l}\text { The key service area of energy efficiency credit includes building energy conservation, } \\
\text { existing and new residential buildings, public buildings, central heating buildings, } \\
\text { energy-saving, optimization of cooling equipment and system, renewable energy } \\
\text { application, etc. }\end{array}$ \\
\hline
\end{tabular}


Table 5. National and industrial standards related to building energy conservation.

\begin{tabular}{|c|c|c|c|c|}
\hline Title & Department of Issue & Date of Issue & Date of Implementation & Related Contents \\
\hline $\begin{array}{l}\text { Design Standard for Energy } \\
\text { Conservation of Civil Buildings } \\
\text { (Heating Residential Buildings) } \\
\text { JGJ26-86 [55] }\end{array}$ & MHURD & 3 March 1986 & 1 August 1986 & $\begin{array}{l}\text { It applies to energy conservation design of central heating residential } \\
\text { buildings and residential heating systems. } \\
\text { New residential buildings should reduce } 30 \% \text { of energy use at energy } \\
\text { use level of } 1980 \text {. }\end{array}$ \\
\hline $\begin{array}{l}\text { Design Standard for Energy } \\
\text { Conservation of Civil Buildings } \\
\text { (Heating Residential Buildings) } \\
\text { (Revision) JGJ26-95 [56] }\end{array}$ & MHURD & 7 December 1995 & 1 July 1996 & $\begin{array}{l}\text { It applies to the design of residential building with central heating in } \\
\text { severe cold and cold regions. The building energy conservation } \\
\text { target increased to } 50 \% \text {. }\end{array}$ \\
\hline $\begin{array}{l}\text { Technical Standard for Energy } \\
\text { Conservation Renovation of } \\
\text { Existing Heating Residential } \\
\text { Building JGJ129-2000 [57] }\end{array}$ & MHURD & 1 October 2000 & 1 January 2001 & $\begin{array}{l}\text { It provides the judgment principles and methods of building } \\
\text { energy-saving renovation, and the explanation for heat insulation } \\
\text { and heating system transformation. }\end{array}$ \\
\hline $\begin{array}{l}\text { Standard for Energy Efficiency } \\
\text { Inspection of Heating } \\
\text { Residential Buildings } \\
\text { JGJ 132-2001 [58] }\end{array}$ & MHURD & 9 February 2001 & 1 June 2001 & $\begin{array}{l}\text { It applies to the residential buildings with central heating and the test } \\
\text { of energy conservation of energy-saving technical measures in severe } \\
\text { cold regions. }\end{array}$ \\
\hline $\begin{array}{l}\text { Design Standard for Energy } \\
\text { Conservation of Public } \\
\text { Buildings GB 50189-2005 [59] }\end{array}$ & $\begin{array}{l}\text { MHURD } \\
\text { AQSIQ }\end{array}$ & 4 April 2005 & 1 July 2005 & $\begin{array}{l}\text { The annual energy use should reduce } 50 \% \text { for the buildings in } \\
\text { accordance with this energy conservation design standard. }\end{array}$ \\
\hline $\begin{array}{l}\text { Technical Standard for Solar } \\
\text { Water Heating System of Civil } \\
\text { Buildings GB 50364-2005 [60] }\end{array}$ & $\begin{array}{l}\text { MHURD } \\
\text { AQSIQ }\end{array}$ & 5 December 2005 & 1 January 2006 & $\begin{array}{l}\text { It standardizes the design, installation and engineering acceptance of } \\
\text { solar water heating system. It applies to new, expanded and } \\
\text { renovated civil buildings that use solar water heater systems. }\end{array}$ \\
\hline $\begin{array}{l}\text { Standard for Acceptance of } \\
\text { Energy Conservation Building } \\
\text { Construction } \\
\text { GB 50411-2007 [61] }\end{array}$ & $\begin{array}{l}\text { MHURD } \\
\text { AQSIQ }\end{array}$ & 16 January 2007 & 1 October 2007 & $\begin{array}{l}\text { It describes the detailed requirements for energy conservation } \\
\text { projects, field inspection and quality acceptance of building } \\
\text { energy-saving performance. }\end{array}$ \\
\hline $\begin{array}{l}\text { Design Standard for Energy } \\
\text { Conservation of Residential } \\
\text { Buildings in Hot Summer and } \\
\text { Cold Winter Zone } \\
\text { JGJ134-2010 [62] }\end{array}$ & MOHURD & 18 March 2010 & 1 August 2010 & $\begin{array}{l}\text { The building thermal and HVAC design of residential building in hot } \\
\text { summer and cold winter zone must take energy-saving measures. }\end{array}$ \\
\hline $\begin{array}{l}\text { Design Standard for Energy } \\
\text { Conservation of Residential } \\
\text { Buildings in Severe Cold and } \\
\text { Cold Zone JGJ 26-2010 [63] }\end{array}$ & MOHURD & 18 March 2010 & 1 August 2010 & $\begin{array}{l}\text { The building thermal and HVAC design should control the heating } \\
\text { energy use within the limited range. The average energy } \\
\text { conservation ratio should reach } 65 \% \text {. }\end{array}$ \\
\hline $\begin{array}{l}\text { Evaluation Standard for Green } \\
\text { Buildings GB/T50378-2014 [64] }\end{array}$ & $\begin{array}{l}\text { MOHURD } \\
\text { AQSIQ }\end{array}$ & 15 April 2014 & 1 January 2015 & $\begin{array}{l}\text { It applies to the evaluation of green civil buildings, which make clear } \\
\text { to take the conservation assessment of energy, land, water and } \\
\text { material in the whole life cycle of buildings. }\end{array}$ \\
\hline
\end{tabular}


Table 5. Cont.

\begin{tabular}{|c|c|c|c|c|}
\hline Title & Department of Issue & Date of Issue & Date of Implementation & Related Contents \\
\hline $\begin{array}{l}\text { Design Standard for Energy } \\
\text { Conservation of Public } \\
\text { Buildings GB 50189-2015 [65] }\end{array}$ & $\begin{array}{l}\text { MOHURD } \\
\text { AQSIQ }\end{array}$ & 2 February 2015 & 1 October 2015 & $\begin{array}{l}\text { It covers building thermal, and HVAC system, water supply and } \\
\text { drainage, electrical and renewable energy applications, which } \\
\text { achieve the complete coverage in the field of building energy } \\
\text { conservation. }\end{array}$ \\
\hline $\begin{array}{l}\text { Evaluation Standard for Green } \\
\text { Store Buildings GB/T } \\
51100-2015 \text { [66] }\end{array}$ & $\begin{array}{c}\text { MOHURD } \\
\text { AQSIQ }\end{array}$ & 8 April 2015 & 1 December 2015 & $\begin{array}{l}\text { It applies to the new construction, expansion and reconstruction of } \\
\text { different types of store buildings, including store building complex, } \\
\text { single store building and store area in the integrated building. }\end{array}$ \\
\hline $\begin{array}{l}\text { Evaluation Standard for Green } \\
\text { Retrofitting of Existing } \\
\text { Buildings GB/T51141-2015 [67] }\end{array}$ & $\begin{array}{c}\text { MOHURD } \\
\text { AQSIQ }\end{array}$ & 3 December 2015 & 1 August 2016 & $\begin{array}{l}\text { It requires comprehensively evaluating the planning, building, } \\
\text { structure, material, HVAC, water supply and drainage, electrics, } \\
\text { construction management and operation management combined } \\
\text { with building type, function and location. }\end{array}$ \\
\hline
\end{tabular}

Table 6. Plans and programs related to building energy conservation.

\begin{tabular}{|c|c|c|c|}
\hline Title & Department of Issue & Date of Issue & Related Contents \\
\hline Action Plan for Green Building [68] & $\begin{array}{c}\text { NDRC } \\
\text { MOHURD }\end{array}$ & 1 January 2013 & $\begin{array}{l}\text { During the 12th Five-Year period, the renovation of heat metering and } \\
\text { energy-saving for existing residential building in north heating area will } \\
\text { exceed } 400 \text { million } \mathrm{m}^{2} \text {; energy-saving renovation of existing residential } \\
\text { building in hot summer and cold winter zone will reach } 50 \text { million } \mathrm{m}^{2} \text {; } \\
\text { energy-saving renovation of public buildings and public office buildings will } \\
\text { reach } 120 \text { million } \mathrm{m}^{2} \text {. By the end of } 2015,20 \% \text { of new urban buildings will } \\
\text { meet the requirements of green building standards. }\end{array}$ \\
\hline $\begin{array}{l}\text { Action Plan for Energy Development } \\
\text { Strategy (2014-2020) [69] }\end{array}$ & $\csc$ & 19 November 2014 & $\begin{array}{l}\text { Strengthen the building energy planning; implement the improvement project } \\
\text { for building energy efficiency; promote design standard for } 75 \% \text { energy } \\
\text { conservation of residential buildings; accelerate the construction of green } \\
\text { buildings and renovation of existing buildings; implement public building } \\
\text { energy use limits, green building rating and labeling system. By 2020, urban } \\
\text { green building will account for } 50 \% \text { of new building; Accelerate the reform of } \\
\text { heating metering; implement heating metering charges for new buildings and } \\
\text { existing buildings after heating metering renovation. }\end{array}$ \\
\hline $\begin{array}{l}\text { Action Plan for Promoting the } \\
\text { Production and Application of Green } \\
\text { Building Materials [70] }\end{array}$ & $\begin{array}{c}\text { MIIT } \\
\text { MOHURD }\end{array}$ & 31 August 2015 & $\begin{array}{l}\text { By 2018, energy use, total emissions of nitrogen oxide and dust of per unit } \\
\text { added value of building materials industry will decrease by } 8 \% \text { compared } \\
\text { with } 2015 \text {. } \\
\text { For new buildings, the application proportion of green building materials, } \\
\text { green building, demonstrating project and existing buildings innovation will } \\
\text { be } 30 \%, 50 \%, 70 \% \text { \& and } 80 \% \text {, respectively. }\end{array}$ \\
\hline
\end{tabular}


Table 6. Cont

Title

Department of Issue

Date of Issue

Action Plan for Urban Adaptation to

Climate Change [71]

NDRC

MOHURD

4 February 2016

The 13th Five-year Plan Guideline for

National Economic and Social

CSC

18 March 2016

Development [2]

The 13th Five-year Plan for Energy and

Resource Conservation of Public

NGOA

Institutions [72]

NDRC

28 June 2016

The 13th Five-year Plan for Renewable

Energy Development [73]

NDRC

10 December 2016

The 13th Five-year Comprehensive Work Plan for Energy-saving and Emission

Reduction [74]

\section{Related Contents}

Develop passive ultra-low energy use green buildings actively; improve the building air tightness; strengthen the performance in water collecting and heat insulation; ensure indoor environmental quality under the extreme climates; implement urban renewal and comprehensive transformation of aged residential buildings; raise the renovation standard of energy and water saving for the existing buildings.

Implement the action plan of national energy conservation; comprehensively

implement energy conservation in building and public institutions; implement whole industral chain development plan of building energy

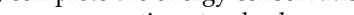
Complete the energy and resource conservation management system; establish a relatively complete system of energy conservation organization and management, policy and standard system, technological promotion system, statistical monitoring system, supervision and evaluation system and propaganda training system. By 2020, the total energy use of public institutions will be controlled within 225 million tce. The comprehensive energy use of each person and the energy use of per unit building area will decrease by $11 \%$ and $10 \%$, respectively.

Popularize the solar water heater system in urban civil buildings and rural areas. By 2020, the accumulated installation area of solar water heater syste will reach 450 million $\mathrm{m}^{2}$; Accelerate the application of solar heating and refrigeration system in buildings. The heat collection area of solar therma utilization will reach 800 million square meters.

Strengthen the building energy conservation. Implement advanced standard leading action of energy conservation, the pilot of ultra-low energy use and near zero energy use buildings.

By 2020, urban green building will account for $50 \%$ of new building; The energy-saving renovation area of existing residential building and public building will exceed 500 million $\mathrm{m}^{2}$ and 100 million $\mathrm{m}^{2}$. Promote the use of solar energy, shallow geothermal energy, air thermal energy and industrial waste heat to satisfy the demand of building energy use. Strengthen the waste heat to satisfy the demand of building energy use. Strengthen the $w$ buildings of public institutions should meet the green building standards; promote energy conservation of public institutions by energy performance contracting; promote government to buy energy performance contracting services actively and explore he decrease by $11 \%$ and $10 \%$, respectively, compared to the level of year 2015 . 


\section{Discussion}

China has established the building energy conservation management system, taking NDRC, MOHURD and NGOA as the leading authorities, supplemented by MIIT, AQSIQ, MOF and SAT. The policy system of building energy conservation is also in place, taking national laws, regulations of the State Council, department rules, standards, plans and programs as components. Building energy conservation in China has achieved remarkable success under the impetus of these policy systems. During the 12th Five-Year period (2011-2015), retrofitting of heat supply metering and energy conservation of existing residential buildings in north heating areas reached 1 billion $\mathrm{m}^{2}$. The area of energy conservation renovation of existing residential building in hot summer and cold winter zone reached 70.9 million $\mathrm{m}^{2}$. More than 10 thousand public buildings passed energy audit [75]. For public institutions, the comprehensive energy use of each person and energy use of per unit building area was $370.73 \mathrm{kgce}$ and $20.55 \mathrm{kgce}$, respectively. Compared to 2010, these two figures dropped by $17.14 \%$ and $13.88 \%$, respectively [72]. Building energy conservation is an important field of energy conservation in China. It is a complex system involving planning, design, construction, management, operation, demolishment, etc. Some problems still need to be resolved for the further development of building energy conservation in China.

The institutional functions of energy conservation management need to be clearly clarified. NDRC is the competent authority of energy conservation. MOHURD is the competent authority of building industry. MIIT is the competent authority of building materials industry. MOHURD is responsible for energy conservation of civil buildings. NGOA is in charge of energy conservation of public institutions. The management institutions and policies of building energy conservation are different in different countries. There is no specialized energy management department in Germany. The Ministry of traffic, construction and urban supervises the building energy conservation and other issues [76]. In Japan, Ministry of Economy, Trade and Industry is in charge of energy management, and the functional departments are in charge of specific building energy conservation affairs [77]. The U.S. Energy Policy Act was published in 1978. It authorizes the Department of Energy to make policies and manage the energy sector $[78,79]$. The "Energy Star", promoted by the Environmental Protection Agency and the Department of Energy, is the most typical building energy-efficiency labeling standard in U.S. [80]. Compared with the building energy conservation effort in the developed countries, the mixed management system has led to the overlapped duties of different government authorities. This also results in the decentralized building energy management across different sectors. Furthermore, there is lack of balance between the different stages of building energy conservation. For instance, the design inspection of building energy conservation is strictly implemented. However, the management of the construction, supervision, completion acceptance, energy conservation test and certification are still underdeveloped in some regions. These have shown negative impacts on the building energy conservation.

The laws and regulations of building energy conservation are still need to be improved. Energy Conservation Law, The Construction Law and other laws were issued for years, but the specific, detailed and operable articles for building energy conservation are lack presently. It is hard to regulate the behaviors of building energy conservation effectively from the aspect of national laws. Regulations of the State Council and department rules such as Regulation on Energy Conservation of State-funded Institutions, Regulation on Energy Conservation of Civil Buildings, and Interim Measures on Energy Audit Management of Public Institutions, have lower legal status compared to national laws. They have weak legal protection for promoting building energy conservation and strengthening the supervision of energy conservation.

The market mechanism of building energy conservation has not been established completely. To lead the rapid development of the building energy conservation, the government provides financial support and tax incentives for energy conservation renovation of public buildings, construction of energy use supervision system, retrofitting of heat supply metering and energy-saving of existing residential buildings, application of the renewable energy in buildings, the production of energy conservation 
building materials, etc. The government also introduced energy efficiency credit guidelines. However, the mechanism of market promoted building energy conservation is still out of place. It is hard to motivate the different stakeholders in the field of building energy conservation. The application of renewable energy in building lacks professional guidance. Building integrated design standard of solar water heater, solar photovoltaic system and ground source heat pump is imperfect. The existing standards do not consider the difference of climatic regions, rural and urban areas. The supporting policy for grid connection of solar photovoltaic system is not fully implemented in some regions, supplied by large initial investment, which affect the development of solar photovoltaic system in the building sector, especially the private users.

The standardization of building energy conservation need to be strengthened. Compared to the developed countries, building energy conservation starts late in China. The standardization work for this is also backward, which reflected by long period of standard formulation, delayed revision of existing standards. This result in standardization work of building energy conservation falls behind the actual work practices. Furthermore, the majority of the 13 existing standards related to building energy conservation are recommended standards. These are not conductive to the standardization and normalization of building energy conservation. If the recommended standards are proved to be effective and become mature in the actual implementing stage, it is necessary to change these recommended standards to mandatory standards.

Building energy conservation in rural areas has not implemented completely. At present, building energy conservation in China is still focused in cities and towns. Rural areas do not get enough attention in this sector. With the continuous improvement of living level in rural areas, the total energy use will increase dramatically. It is necessary to take effective measures to improve building energy efficiency in rural areas, and especially the indoor thermal comfort in winter in northern China.

Building energy conservation from whole-of-life perspective did not receive adequate attention. Legal measures are taken to keep the sustainable development of countries, including sustainable building [81]. However, the assessment of the energy demand for residential buildings mainly concentrates on the energy consumption of operation, especially the thermal energy. In contrast, the embodied energy and the transportation energy consumption of buildings are usually ignored [82]. The key issues of the building energy assessment are energy calculation and life cycle analysis, although they are mainly overlooked in regulations and certification recommendations [83]. It is crucial to examine the building energy conservation by a whole-of-life approach $[84,85]$. These include the embodied, operational and user-transport energy reduction measures for the building sector [86]. These three kinds of energy consumption are almost equally important [83]. It is necessary to introduce comprehensive policies related to building energy conservation so that the energy demand in the whole life cycle of buildings can be reduced [87].

\section{Conclusions}

China has specified the control target of total energy use as below 5 billion tce by 2020. In the Paris Agreement, China pledged that its carbon dioxide emissions would reach peak before 2030. As the world's largest energy consumer and carbon emitter, China is presented significant challenge in controlling energy use and reducing carbon emissions. Building energy conservation plays an important role in the overall framework of energy conservation and emission reduction in China.

In the aspect of institutional system for building energy conservation, a comprehensive management framework was established in China. NDRC, MOHURD and NGOA are the leading authorities, and are assisted by MIIT, AQSIQ, MOF and SAT. The policy mechanism of building energy conservation includes three levels, which take national laws as the lead, and regulations of the State Council, department rules, standards, plans and programs as supplements. Given the comparatively completed institutional and policy system, remarkable achievements have been made on building energy conservation. The energy-saving capacity reached 116 million tce during the 12th Five-year Plan period. The issues need to be improved for building energy conservation in China include making 
explicit responsibility for various government departments, completing national laws and standard system, establishing the market leading mechanism, implementing professional guidance of renewable energy application, and the comprehensive promotion in rural areas.

As the effect of building energy conservation is a comprehensive result of the various policies, it is difficult to quantify the effectiveness of a specific policy in a certain period. Similarly, much attention is paid to the operational stage for building energy conservation in China currently. More achievements will be made if the building energy conservation can be managed from the whole-of-life perspective. A case study with detailed actual operation data will provide quantitative evidence for this issue.

Acknowledgments: This research is supported by the National Key R\&D Plan (2017YFC0703100), National Natural Science Foundation (41471461), and the Fundamental Research Funds of Shandong University (2015JC056).

Author Contributions: The study was designed by Xueliang Yuan and Qignsong Wang. The information from yearbooks and official websites were retrieved by Xiaoyu Zhang and Jiaxin Liang. The results were analyzed by Xueliang Yuan and Jian Zuo. The policies related to the research were reviewed by Qingsong Wang. English corrections were completed by Jian Zuo.

Conflicts of Interest: The authors declare no conflict of interest. The founding sponsors had no role in the design of the study; in the collection, analyses, or interpretation of data; in the writing of the manuscript, and in the decision to publish the results.

\section{References}

1. NBS. National Economic and Social Development Statistical Bulletin 2016. 2017. Available online: http:/ /www.stats.gov.cn/tjsj/zxfb./201702/t20170228_1467424.html (accessed on 10 February 2017).

2. CSC. The 13th Five-Year Plan Guideline for National Economic and Social Development. 2016. Available online: http:/ / www.gov.cn/xinwen/2015-11/03/content_2959432.htm (accessed on 10 February 2017).

3. Sun, X.; Zhang, B.; Tang, X.; McLellan, B.C.; Höök, M. Sustainable Energy Transitions in China: Renewable Options and Impacts on the Electricity System. Energies 2016, 9, 980. [CrossRef]

4. NBS. China Statistical Yearbook 2016; China Statistics Press: Beijing, China, 2016.

5. Juaidi, A.; AlFaris, F.; Montoya, F.G.; Agugliaro, F.M. Energy benchmarking for shopping centers in Gulf Coast region. Energy Policy 2016, 91, 247-255. [CrossRef]

6. Jiang, R.; Li, R.R. Decomposition and Decoupling Analysis of Life-Cycle Carbon Emission in China's Building Sector. Sustainability 2017, 9, 793. [CrossRef]

7. Zhao, L.; Zhou, Z.N. Developing a Rating System for Building Energy Efficiency Based on In Situ Measurement in China. Sustainability 2017, 9, 208. [CrossRef]

8. Choi, B.E.; Shin, J.H.; Lee, J.H.; Kim, S.S.; Cho, Y.H. Development of Decision Support Process for Building Energy Conservation Measures and Economic Analysis. Energies 2017, 10, 324. [CrossRef]

9. Nejat, P.; Jomehzadeh, F.; Taheri, M.M.; Gohari, M.; Majid, M.Z.A. A global review of energy consumption, $\mathrm{CO}_{2}$ emissions and policy in the residential sector (with an overview of the top ten $\mathrm{CO}_{2}$ emitting countries). Renew. Sustain. Energy Rev. 2015, 43, 843-862. [CrossRef]

10. Chwieduk, D.A. Towards modern options of energy conservation in buildings. Renew. Energy 2017, 101, 1194-1202. [CrossRef]

11. Vringer, K.; Middelkoop, M.V.; Hoogervorst, N. Saving energy is not easy: An impact assessment of Dutch policy to reduce the energy equirements of buildings. Energy Policy 2016, 93, 23-32. [CrossRef]

12. Chen, G. Research on economic incentive and policies to promote construction energy conservation. Energy Conserv. 2013, 12, 98-100.

13. Guo, F.; Kurdgelashvili, L.; Bengtsson, M.; Akenji, L. Analysis of achievable residential energy-saving potential and its implications for effective policy interventions: A study of Xiamen city in southern China. Renew. Sustain. Energy Rev. 2016, 62, 507-520. [CrossRef]

14. Shaikh, P.H.; Nor, N.B.M.; Sahito, A.A.; Nallagownden, P.; Elamvazuthi, I.; Shaikh, M.S. Building energy for sustainable development in Malaysia: A review. Renew. Sustain. Energy Rev. 2017, 75, 1392-1403. [CrossRef]

15. SCNPC. The Main Functions of NDRC. 2014. Available online: http:/ / www.gov.cn/fuwu/2014-02/22/ content_2618624.htm (accessed on 10 February 2017).

16. SCNPC. Regulations of the Main Functions, Internal Institutions and Staffing of MOHURD. 2008. Available online: http:/ / www.mohurd.gov.cn/gyjsb / zyzz/index.html (accessed on 10 February 2017). 
17. SCNPC. The Main Functions of MIIT. 2015. Available online: http://www.miit.gov.cn/n1146285/c3722500/ content.html (accessed on 10 February 2017).

18. SCNPC. Regulations of the Main Functions, Internal Institutions and Staffing of AQSIQ. 2008. Available online: http:/ / www.aqsiq.gov.cn/_jxw / zjxw / zjftpxw/200808/t20080812_85293.htm (accessed on 12 February 2017).

19. SCNPC. The Main Functions of the NGOA. 2012. Available online: http://www.gov.cn/banshi/qy/rlzy/ 2012-11/12/content_2262730.htm (accessed on 12 February 2017).

20. SCNPC. The Main Functions of MOF. 2014. Available online: http://www.gov.cn/fuwu/2014-02/22/ content_2618673.htm (accessed on 12 February 2017).

21. SCNPC. The Main Functions of SAT. 2014. Available online: http://www.gov.cn/fuwu/2014-02/22/ content_2618760.htm (accessed on 12 February 2017).

22. SCNPC. Energy Conservation Law. 2007. Available online: http://www.gov.cn/flfg/2007-10/28/content_ 788493.htm (accessed on 12 February 2017).

23. SCNPC. Cleaner Production Promoting Law. 2012. Available online: http://www.npc.gov.cn/npc/xinwen/ 2012-03/01/content_1695166.htm (accessed on 12 February 2017).

24. SCNPC. Renewable Energy Law. 2005. Available online: http://www.gov.cn/ziliao/flfg/2005-06/21/ content_8275.htm (accessed on 14 February 2017).

25. SCNPC. Circular Economy Promotion Law. 2008. Available online: http://www.gov.cn/flfg/2008-08/29/ content_1084355.htm (accessed on 14 February 2017).

26. SCNPC. Construction Law. 2011. Available online: http://www.gov.cn/flfg/2011-04/25/content_1851696. htm (accessed on 14 February 2017).

27. CSC. Provisional Regulations of Management for Energy Conservation. 1986. Available online: http:/ / fgk.chinalaw.gov.cn/article/xzfg/198601/19860100268284.shtml (accessed on 14 February 2017).

28. CSC. Regulation on the Administration for Environmental Protection of Construction Projects 1998. Available online: http:/ /www.zhb.gov.cn/gzfw_13107/zcfg/fg/xzfg/201605/t20160522_343327.shtml (accessed on 15 February 2017).

29. CSC. Regulation on the Quality Management of Construction Projects. 2000. Available online: http: / / www.gov.cn/flfg/2005-08/06/content_20998.htm (accessed on 15 February 2017).

30. CSC. Regulation on Energy Conservation of State-Funded Institutions. 2008. Available online: http: / / www.gov.cn/flfg/2008-08/11/content_1069579.htm (accessed on 15 February 2017).

31. CSC. Regulation on Energy Conservation of Civil Buildings. 2008. Available online: http://www.gov.cn/ flfg/2008-08/07/content_1067062.htm (accessed on 14 February 2017).

32. MHURD. Guidance on the Development of Energy and Land Saving Houses and Public Buildings. 2005. Available online: http://www.mohurd.gov.cn/zcfg/jsbwj_0/jsbwjjskj/200611/t20061101_158479.html (accessed on 14 February 2017).

33. MHURD. Regulation on Energy Conservation Management of Civil Buildings. 2006. Available online: http://www.mohurd.gov.cn/zcfg/jsbgz/200611/t20061101_159082.html (accessed on 14 February 2017).

34. MHURD; MOF. Implementation Suggestions on Strengthening the Administration of Energy Conservation in Office Buildings and Large-Scale Public Buildings. 2007. Available online: http:/ / www.mohurd.gov.cn/ zcfg/jsbwj_0/jsbwjjskj/200710/t20071026_158566.html (accessed on 20 February 2017).

35. MOF; MOHURD. Notice on Renewable Energy Application Demonstration Projects of Urban Construction. 2009. Available online: http://www.gov.cn/zwgk/2009-07/09/content_1360900.htm (accessed on 20 February 2017).

36. MOF; MOHURD. Notice on Renewable Energy Application Demonstration Projects in Rural Areas. 2009. Available online: http://www.gov.cn/zwgk/2009-07/09/content_1360930.htm (accessed on 20 February 2017).

37. MOF; MOHURD. Notice on Further Promoting the Application of Renewable Energy in Building. 2011. Available online: http://www.mohurd.gov.cn/zcfg/jsbwj_0/jsbwjjskj/201103/t20110311_202814.html (accessed on 20 February 2017).

38. MOF; MOHURD. Notice on Further Promoting Energy Conservation of Public Buildings. 2011. Available online: http:/ / www.gov.cn/zwgk/2011-05/11/content_1861716.htm (accessed on 20 February 2017).

39. MOHURD; MIIT. Evaluation Guidelines for Green Building Materials. 2015. Available online: http:/ / www.mohurd.gov.cn/wjfb/201510/t20151022_225340.html (accessed on 22 February 2017). 
40. MOHURD. Technical Guidelines for Passive Ultra-Low Energy Consumption Green Buildings (Trial Implementation in Residential Buildings). 2015. Available online: http://www.mohurd.gov.cn/wjfb/ 201511/t20151113_225589.html (accessed on 22 February 2017).

41. NGOA; NDRC; MOF. Implementation Suggestions on Promoting Public Institutions to Save Energy and Resources, and Promoting the Construction of Ecological Civilization. 2015. Available online: http:/ /www. ggj.gov.cn/ggjgjn/ggjgjnzwgk/ggjgjntzgg/201601/t20160119_289379.htm (accessed on 22 February 2017).

42. NDRC; NGOA. The Interim Measures on Energy Audit Management of Public Institutions. 2015. Available online: http:/ / www.sdpc.gov.cn/gzdt/201601/t20160114_771361.html (accessed on 22 February 2017).

43. MOHURD. The Interim Measures on Acceptance and Operation Management of Provincial Energy Use Monitoring Platform for Public Buildings. 2016. Available online: http://www.mohurd.gov.cn/wjfb/ 201604/t20160415_227217.html (accessed on 25 February 2017).

44. MOHURD. Energy Audit Guidelines for Public Institutions. 2016. Available online: http:/ /www.mohurd. gov.cn/wjfb/201612/t20161219_230018.html (accessed on 25 February 2017).

45. MOF. The Interim Regulation on Special Funds for Energy Conservation of Government Office Buildings and Large-Scale Public Buildings. 2007. Available online: http:/ / www.mohurd.gov.cn/zcfg/xgbwgz/200710/ t20071031_159875.html (accessed on 25 February 2017).

46. MOF. The Interim Regulation on Reward for Heat Supply Metering and Energy Conservation of Existing Residential Buildings in North Heating Areas. 2007. Available online: http:/ / www.mohurd.gov.cn/zcfg/ xgbwgz/200712/t20071228_159878.html (accessed on 25 February 2017).

47. MOF. The Interim Regulation on Financial Subsidy Funds for Production and Usage of Renewable Energy-Saving Building Materials. 2008. Available online: http:/ /www.china.com.cn/policy/txt/2008-10/ 28/content_16679391.htm (accessed on 25 February 2017).

48. MOF. The Interim Regulation on Financial Subsidy Funds for the Application of Solar Photovoltaic Buildings. 2009. Available online: http://www.gov.cn/zwgk/2009-03/26/content_1269258.htm (accessed on 25 February 2017).

49. MOF; MOHURD. Implementation Plans of Renewable Energy Building Application City. Beijing, 2009. Available online: http:/ /www.gov.cn/zwgk/2009-07/09/content_1360900.htm (accessed on 25 February 2017).

50. MOF; MOHURD. Implementation Plans of Accelerating the Application of Renewable Energy Buildings in Rural Area. 2009. Available online: http:/ /www.gov.cn/zwgk/2009-07/09/content_1360930.htm (accessed on 25 February 2017).

51. MOF; SAT; NDRC. The Income Tax Preferential Catalogue for the Projects of Environmental Protection, Energy and Water Saving. 2009. Available online: http://www.chinatax.gov.cn/n810341/n810755/ c1146489/content.html (accessed on 25 February 2017).

52. MOF; MOHURD. Suggestions on Implementation of Promoting the Energy-Saving Renovation of Existing Residential Buildings in Hot Summer and Cold Winter Zone. 2012. Available online: http:/ /www.gov.cn/ zwgk/2012-04/17/content_2115207.htm (accessed on 25 February 2017).

53. MOF. The Interim Regulation on Subsidy Funds for Energy-Saving Renovation of Existing Residential Buildings in Hot Summer and Cold Winter Zone. 2012. Available online: http:/ / www.mohurd.gov.cn/zcfg/ xgbwgz/201205/t20120503_209706.html (accessed on 26 February 2017).

54. CBRC; NDRC. Guideline for Energy Efficiency Credit. 2015. Available online: http:/ /www.sdpc.gov.cn/ zcfb/zcfbqt/201501/t20150123_661043.html (accessed on 26 February 2017).

55. MHURD. Regulation on Energy Conservation in Civil Buildings (Heating Residential Buildings) JGJ26-86. 1986. Available online: http:/ / www.csres.com/detail/20875.html (accessed on 26 February 2017).

56. MHURD. Regulation on Energy Conservation in Civil Buildings (Heating Residential Buildings) (Revision) JGJ26-95. 1995. Available online: http://www.spsp.gov.cn/page/P610/621.shtml (accessed on 26 February 2017).

57. MHURD. Technical Standard for Energy Conservation Renovation of Existing Heating Residential Building. JGJ129-2000. 2000. Available online: http://www.spsp.gov.cn/page/P264/206.shtml (accessed on 26 February 2017).

58. MHURD. Standard for Energy Efficiency Inspection of Heating Residential Buildings. JGJ 132-2001. 2001. Available online: http:/ / www.spsp.gov.cn/page/P874/894.shtml (accessed on 26 February 2017).

59. MHURD; GAQSIQ. Design Standard for Energy Conservation of Public Buildings GB 50189-2005. 2005. Available online: http:/ / www.spsp.gov.cn/page/P424/525.shtml (accessed on 26 February 2017). 
60. MHURD; GAQSIQ. Technical Standard for Solar Water Heating System of Civil Buildings. GB 50364-2005. 2005. Available online: http:/ / www.spsp.gov.cn/page/P424/269.shtml (accessed on 26 February 2017).

61. MHURD; GAQSIQ. Standard for Acceptance of Energy Conservation Building Construction. GB 50411-2007. 2007. Available online: http:/ / www.spsp.gov.cn/page/P424/318.shtml (accessed on 26 February 2017).

62. MOHURD. Design Standard for Energy Conservation of Residential Buildings in Hot Summer and Cold Winter Zone. JGJ134-2010. 2012. Available online: http://www.spsp.gov.cn/page/P1030/747.shtml (accessed on 26 February 2017).

63. MOHURD. Design Standard for Energy Conservation of Residential Buildings in Severe Cold and Cold Zone. JGJ 26-2010. 2010. Available online: http:/ / www.spsp.gov.cn/page/P1032/550.shtml (accessed on 26 February 2017).

64. MOHURD; GAQSIQ. Evaluation Standard for Green Buildings. GB/T50378-2014. 2014. Available online: http:/ / www.spsp.gov.cn/page/P1466/7.shtml (accessed on 27 February 2017).

65. MHURD; GAQSIQ. Design Standard for Energy Conservation of Public Buildings GB 50189-2015. 2015. Available online: http:/ / www.risn.org.cn/xxbz/showforcestandard.aspx?guid=e364ea94-05d3-4098-a1a6e05dd1248f63 (accessed on 27 February 2017).

66. MOHURD; GAQSIQ. Evaluation Standard for Green Store Buildings. GB/T 51100-2015. 2015. Available online: http:/ / www.spsp.gov.cn/page/P1854/328.shtml (accessed on 27 February 2017).

67. MOHURD; GAQSIQ. Evaluation Standard for Green Retrofitting of Existing Buildings. GB/T51141-2015. 2015. Available online: http://www.mohurd.gov.cn/wjfb/201601/t20160126_226441.html (accessed on 27 February 2017).

68. NDRC; MOHURD. Action Plan for Green Building. 2013. Available online: http://www.gov.cn/zwgk/ 2013-01/06/content_2305793.htm (accessed on 27 February 2017).

69. MOHURD; MIIT. Action Plan for Promoting the Production and Application of Green Building Materials. 2015. Available online: http://www.mohurd.gov.cn/wjfb/201509/t20150906_224666.html (accessed on 27 February 2017).

70. CSC. Action Plan for Energy Development Strategy (2014-2020). 2014. Available online: http:/ / www.gov. cn/xinwen/2014-11/19/content_2780748.htm (accessed on 27 February 2017).

71. NDRC; MOHURD. Action Plan for Urban Adaptation to Climate Change. 2016. Available online: http:/ / www.sdpc.gov.cn/zcfb/zcfbtz/201602/t20160216_774721.html (accessed on 27 February 2017).

72. NDRC; NGOA. The 13th Five-Year Plan for Energy and Resource Conservation of Public Institutions. 2015. Available online: http:/ / www.cnqyzc.com/News.aspx?id=23557 (accessed on 27 February 2017).

73. NDRC. The 13th Five-Year Plan for Renewable Energy Development. 2016. Available online: http:/ / www.sdpc.gov.cn/zcfb/zcfbtz/201612/t20161216_830264.html (accessed on 28 February 2017).

74. CSC. The 13th Five-Year Comprehensive Work Plan for Energy-Saving and Emission Reduction. 2017. Available online: http://www.mof.gov.cn/zhengwuxinxi/caizhengxinwen/201701/t20170106_2515580.htm (accessed on 28 February 2017).

75. NDRC. China's Policies and Actions on Climate Change 2015. Available online: http:/ /www.sdpc.gov.cn/ gzdt/201611/t20161102_825493.html (accessed on 28 February 2017).

76. Renn, O.; Marshall, J.P. Coal, nuclear and renewable energy policies in Germany: From the 1950s to the "Energiewende". Energy Policy 2016, 99, 224-232. [CrossRef]

77. Shortall, R.; Kharrazi, A. Cultural factors of sustainable energy development: A case study of geothermal energy in Iceland and Japan. Renew. Sustain. Energy Rev. 2017, 79, 101-109. [CrossRef]

78. Lokey, E. A critical review of the Energy Policy Act of 2005's treatment of hydrogen. Int. J. Hydrog. Energy 2007, 32, 1673-1679. [CrossRef]

79. Dixon, R.K.; Mcgowan, E.; Onysko, G.; Scheer, R.M. US energy conservation and efficiency policies: Challenges and opportunities. Energy Policy 2010, 38, 6398-6408. [CrossRef]

80. Li, H.; Carrión-Flores, C.E. An analysis of the ENERGY STAR ${ }^{\circledR}$ program in Alachua County, Florida. Ecol. Econ. 2017, 131, 98-108. [CrossRef]

81. Szalay, A.Z.-Z. What is missing from the concept of the new European Building Directive? Build. Environ. 2007, 42, 1761-1769. [CrossRef]

82. Stephan, A.; Crawford, R.H.; Myttenaere, K.D. Towards a comprehensive life cycle energy analysis framework for residential buildings. Energy Build. 2012, 55, 592-600. [CrossRef] 
83. Casals, X.G. Analysis of building energy regulation and certification in Europe: their role, limitations and differences. Energy Build. 2006, 38, 381-392. [CrossRef]

84. Stephan, A.; Crawford, R.H. The relationship between house size and life cycle energy demand: Implications for energy efficiency regulations for buildings. Energy 2016, 116, 1158-1171. [CrossRef]

85. Blengini, G.A.; Carlo, T.D. The changing role of life cycle phases, subsystems and materials in the LCA of low energy buildings. Energy Build. 2010, 42, 869-880. [CrossRef]

86. Stephan, A.; Stephan, L. Life cycle energy and cost analysis of embodied, operational and user-transport energy reduction measures for residential buildings. Appl. Energy 2016, 161, 445-464. [CrossRef]

87. Crawford, R.H.; Bartak, E.L.; Stephan, A.; Jensen, C.A. Evaluating the life cycle energy benefits of energy efficiency regulations for buildings. Renew. Sustain. Energy Rev. 2016, 63, 435-451. [CrossRef]

(C) 2017 by the authors. Licensee MDPI, Basel, Switzerland. This article is an open access article distributed under the terms and conditions of the Creative Commons Attribution (CC BY) license (http:// creativecommons.org/licenses/by/4.0/). 